\title{
Learning Model of History to Wetlands for Historical Consciousness
}

\author{
$1^{\text {st }}$ Herry Porda Nugroho Putro* \\ Department of Social Sciences Education, Faculty \\ of Teaching and Training Education, \\ Universitas Lambung Mangkurat, Banjarmasin, \\ Indonesia \\ pordabanjar@ulm.ac.id
}

\author{
$2^{\text {nd }}$ Deasy Arisanty \\ Department of Geography Education, Faculty of \\ Teaching and Training Education, \\ Universitas Lambung Mangkurat, Banjarmasin, \\ Indonesia \\ $3^{\text {rd }}$ Mohamad Zaenal Arifin Anis \\ Department of History Education, Faculty of \\ Teaching and Training Education, \\ Universitas Lambung Mangkurat, Banjarmasin, \\ Indonesia
}

historical awareness. The results of the study are scientific learning models in the form of models with stages in the form of; problem formulation, observation, reporting, presentation, and conclusions. Historical heritage in the city of Banjarmasin consists of places of worship, traditional houses, museums, old graves and floating markets. Implementation of the model was carried out in small trials in one group; trials were limited to three groups, and extensive trials in six groups. The wetland environment can be used as a development of historical learning and learning resources to foster historical awareness.

Keywords-Wetlands, History Learning, Inquiry, Problem Solving, Historical Consciousness

long time for improvement. NUS Singapore has developed learning by solving problems creatively. Students are faced with real problems and given assignments to solve [2].

Learning history is important from the national aspect, as the formation of nationalism. The psychological aspect of learning history knows about development, change, and continuity. This can foster awareness and form personal respect and respect for each other, in the form of learning according to Bloom's Taxonomy (Nurhasanah, 
Maryuni, Putra, 2016, p.21). Historical methods can be implemented in history learning, so learning history becomes scientific. Learning history can be taught according to the nature of science inform scientific, an application-related, student-centered learning situation must be created which starts with a concrete applicatio [3].

The environment stores learning resources, there are sites, historical objects, and documents. Students can find information in their environment and explore, so that they can grow their historical awareness. For this reason, historical learning models need to be developed in accordance with environmental characteristics.

\section{Library Studies}

Historical education at this time has an important meaning as a basis for understanding the development of society due to the Industrial Revolution 4.0. The ability to think critically can be grown from learning history, so that it can understand various political, social, economic, and cultural events that occur. Learning history can be used to study various changes due to various information [4]. The environment is a social force, there are three parts in the form of local, national, and international. Every event is always related, cause and effect. Learning from the environment can develop social competence and awareness in the form of thinking skills and caring for the environment [5]. The selection of the environment as a source of learning must pay attention to the background of students, so it is in accordance with the values prevailing in society. Learning becomes meaningful and useful for life.

Wetland environment is an area that has land consisting of water or surrounded by water, in the form of rivers, swamps, lakes [6]. Ecosystems continue to develop over time, be it flora, fauna, and humans. Flora in the wetland environment can meet the needs of human life, as food, as well as basic building materials and infrastructure. Fauna in the wetland environment can be managed to meet the needs of life both food, economy, and culture. The wealth of the wetland environment has fostered creativity in the form of culture. Traditional houses, special food is authentic evidence of the people's struggle to adapt to the wetland environment.

The existence of the river has produced a variety of life activities. During the Sultanate of Banjar, the river became the economic center; it could control the hinterland or inland areas for economic control. According to Fong [7] that in the $18^{\text {th }}$ century boats played an important role in the Sultanate's economy, especially in the pepper trade. Boats are used to transport the community's agricultural produce, as well as the community fulfilling the necessities of life through rivers using boats.

The Banjar War showed that the river was a means of successful struggle against the Dutch, the fighters fought using boats and small canoes. The river has played an important role in the struggle of the Banjar people in the $19^{\text {th }}$ and $20^{\text {th }}$ centuries. The fighters succeeded in sinking the warship of the Dutch Kingdom of unrest in December 1859. Historical events in Banjarmasin are always related to the river, because the river becomes the lifeblood of life, the development of power, and the spread of culture. Saleh [8] sees in the past all cities where government, trade is at the crossing of a river or river mouth. If we look at the historical course of the city of Banjarmasin, its growth has benefited from its location at the mouth of a river large where large ships are anchored. This condition allows the development of power.

One of the developments in Banjarmasin as a trade center was due to the move of routes trade to the Moluccas through Makassar, South Kalimantan, China returning to Makassar and continuing to Banten and India. In the mid-17th century Banjarmasin had developed very rapidly. Even though the VOC controlled the Barito River, Banjar pepper continued to flow out of Banjarmasin through small rivers. The harbor is full of sailboats, although there is a contract with the Dutch free trade continues. Added by Poesponegoro [7] wars in the area of South Kalimantan, especially Banjarmasin are usually carried out in rivers. Wooden blocks and rafts were built in the river. Cerucuk (large blocks 
which are planted in water) are installed to hold the enemy at a certain distance, small blocks which are sharp are also planted in water and are not visible. The boats that are used in South Kalimantan to fight in rivers are called Jukung, besides that there is a chop that can go fast.

Wetland environment as a source of learning according to Bruner's opinion is discovery, tracing historical events that exist in case. Gagne said that students can learn to connect the surrounding environment with symbols, ideas, and concepts. Historical awareness means realizing the historical reality that humans from time to time experience changes and developments continuously, means being able to think historically, namely thinking chronologically, comprehensively, interpreting, research capabilities, and analyzing historical issues [9].

\section{METHOD}

This research is a research and development [10]. Research conducted in the form of pre-research in the form of library research and field research activities in lectures and learning resources along the river, then a draft of learning models was built and a trial was conducted in small groups, limited groups and broad groups. Modifications of research and development are in the following fig.1.

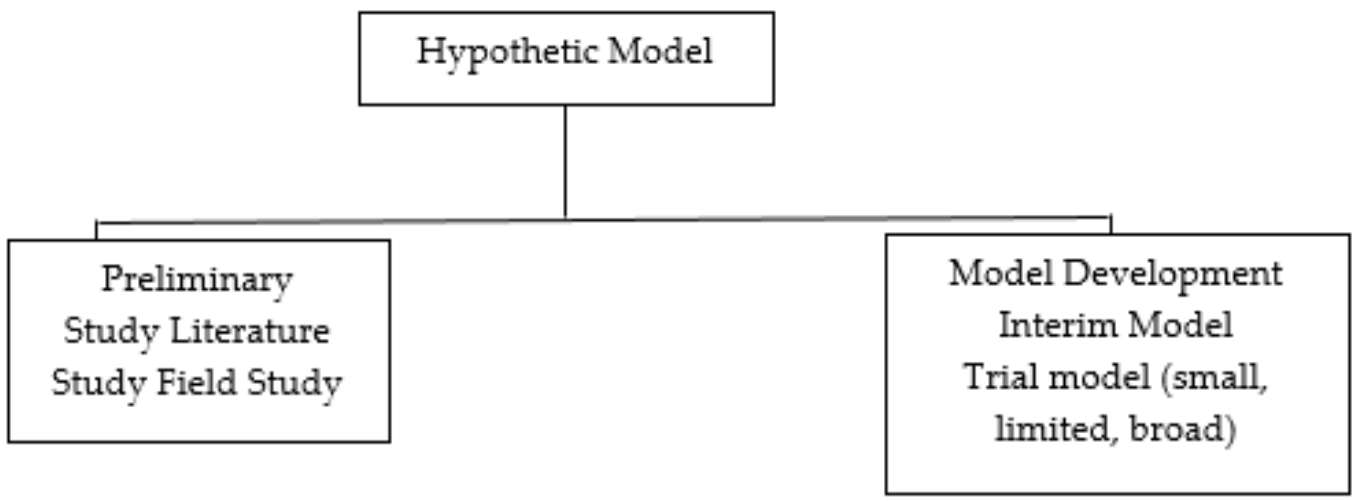

Figure 1 Chart of Research and Development Modifications Research

The research locations in Banjarmasin and Study Programs Educational history of Universitas Lambung Mangkurat. Data collection about historical sources is in the Banjarmasin city. Data collection about historical awareness in the Study Program. Research subjects were 250 students of the Historical Education Study Program. The data were collected through observation in the field and in the classroom. Historical awareness data was collected from student observations and presentations. Collection of student history awareness data with field activity evaluation tables and presentation assessment tables in class. The aspects assessed are: timeliness, sincerity, tidiness, suitability of objects, problems, identification, sources, analysis, and conclusions. The aspects of class presentations are: timeliness, tidiness, cooperation, responses, arguments, respect for opinions, media, understanding, appreciation, sincerity. Scores are: 50-60 (less), 61-70 (enough), 71-80 (good), 81-100 (excellent). Data analysis was carried out since the process of data collection was called the process of analysis, reduction, data presentation, data verification, and drawing conclusions. 


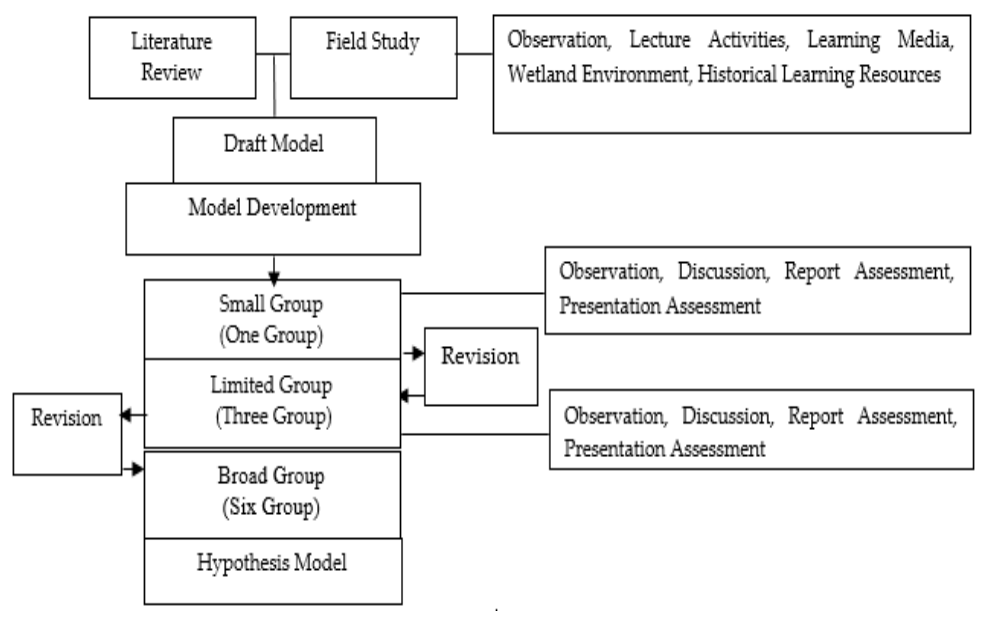

Figure 2 Research Flowchart

\section{RESULTS AND DISCUSSION}

\section{Research Locations}

River for Banjarmasin community is the center of life, since a long time ago various activities developed along the river. The results of preliminary studies have found historical sources in the form of relics in the form of buildings, located on the banks of rivers and swampy areas. The building is a historical building in the form of a place of worship and also the tomb of the kings around the 16th century. In addition, historical documents were also found in the form of letters or historical documents about the struggle of the people in Banjarmasin at the time of maintaining independence in 1945. Rivers and swamps have been a medium of community activity for a long time.

The following map is a description of historical relics in the city of Banjarmasin, historical relics in the Banjarmasin city consist of; Surgi Mufti Tombs Cultural Heritage, Prince Antasari Tombs Complex, Sultan Suriansyah Tombs Complex, Kuin Floating Market, Sultan Suriansyah Mosque, Museum Sabilal Muhtadin Sudimampir, Traditional House, Sasirangan Village, Jami Mosque.

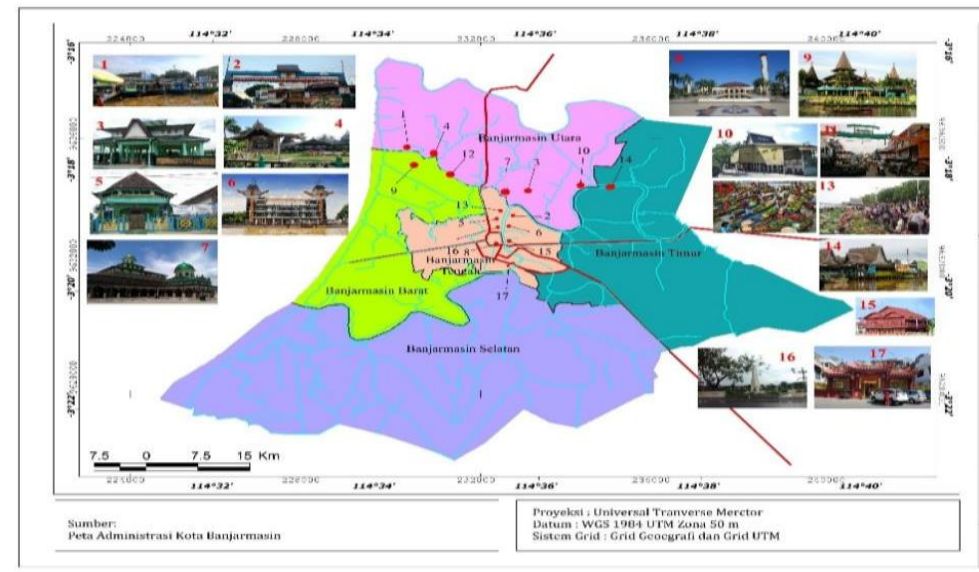

Figure 3 Historical Heritage Map in Banjarmasin City 


\section{Model Development}

The learning model developed is Student Centered Learning (SCL) in the form of cooperative learning, namely discussion. Lectures by discussing developing activities and forms of a studentcentered approach. In activities with discussion methods students form groups to discuss lecture material from lecturers, so that cooperation develops, mutual feedback, respecting the opinions of group members, and making arguments based on sources. Small group discussion in the form of generating ideas, summarizing important points, accessing levels skills and knowledge reviewing topics in the previous class, studying, exercises, quizzes, writing assignments, processing outcomes learning at the end of class, commenting on class progress, comparing theories, issues and interpretations, solving problems, brainstorming. The developed learning model is in the form of a chart as follows:

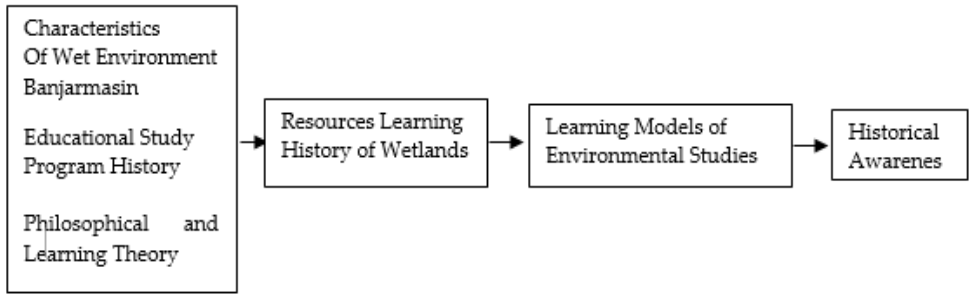

Figure 4 Development Chart Model-Based learning history to wetland to historical consciousness

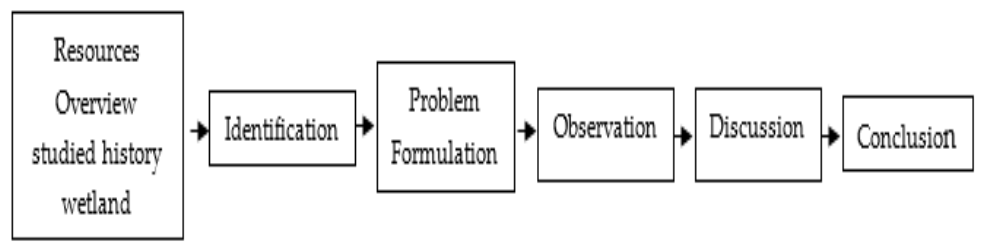

Figure 5 Step learning

Outcomes learning is the awareness of history: the student is able to formulate the problem historical sources, students are able to analyze the historical events in the area wet, students are able to identify historical sources in the wetland environment, students are able to interpret historical sources in the wetland environment, students are able to compile a source report in parallel rah in the wetland environment. The results of observations by students are places of historical events along the river as shown below:

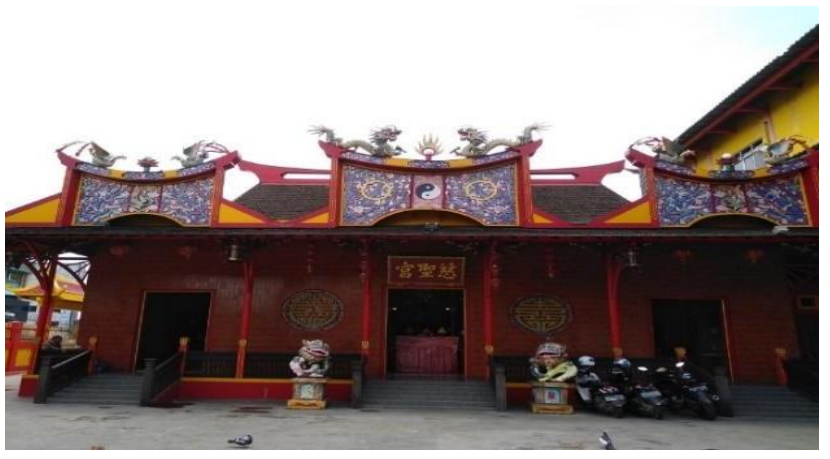

Figure 6 Place of worship of Chinese people 


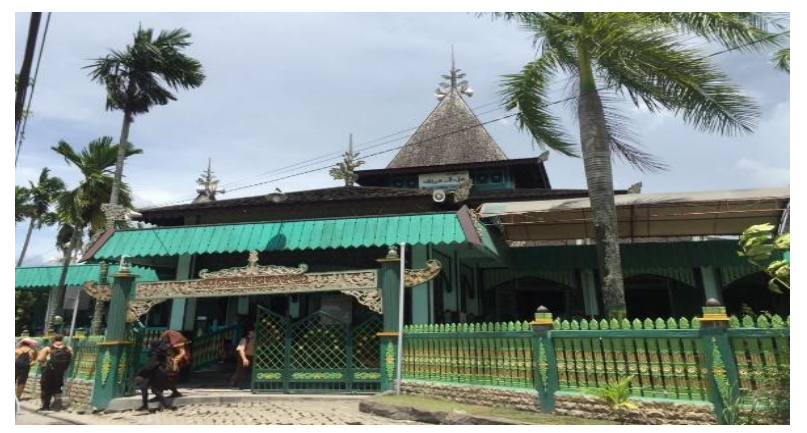

Figure 7 The first mosque in Banjarmasin in the $16^{\text {th }}$ century

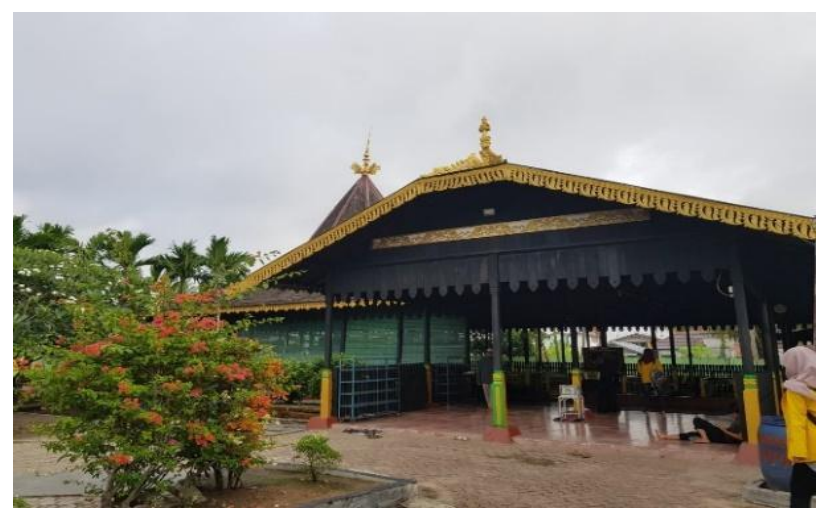

Figure 8 Tomb complex of the kings

The picture above shows that in the wetland environment there are also activities from China in the form of a Chinese shrine called Klengteng, around the place there is a village known as Chinatown. This shows that relations with Chinese culture have been established for a long time.

Islam as the majority religion is marked by the first mosque that was founded around the sixteenth century by the first Sultan, Sultan Suriyansyah. The process of Islamization of relations with the Sultanate of Demak in Java in the succession between Prince Samudra or Sultan Suriansyah with his uncle Raden Tumenggung.

Not far from the Suriansyah Mosque there are tombs of kings, nobles and scholars who have contributed to the development of Islam, Khatib Dayan, and their followers in the sixteenth century.

\section{Trial}

Model testing is carried out in two stages. The first stage is at the historical heritage site in the wetland environment, the second stage is in the classroom. Model Learning models to increase awareness through historical sources in the wetland environment are carried out with field activities and exposure. Historical awareness can be seen in the results of field activities and presentations. In field activities the results of the report become an indicator of awareness of the history students. This can be seen from the ability of students to observe, identify, analyze and compile reports. In small group trials the results of understanding and application of activities can be seen by identifying, analyzing, concluding, and compiling reports in sufficient categories with an average of 65 . After making revisions and reflections on the next trial that is a limited trial of three groups, with fifteen people students obtained an average yield for field activities 
was 76.4. This shows the historical awareness of historical sources in the wetland environment in either category. Model development was carried out more broadly in six groups with 28 students. The results of the fieldwork show that historical awareness of historical students has increased. This is shown by the report score of the results of fieldwork on average 83.56 included in the excellent category.

Historical awareness of students can be seen at the time of exposure to the results of field observations in the form of timeliness, cooperation, attitude to answer, argue, respect opinions, use of media, understanding of historical sources and events, as well as seriousness in discussion. The results of limited trials show the average score of students is 70.13 , meaning that the category is good. While the lowest score of students is 69.5 and the highest score is 70.5. In limited trials the scores obtained are as follows: for the lowest average student score is 75.7 while the highest is 78.5 . The average score of the group is the lowest $76.4,78$ is the highest score the overall total score is 76.7. The results of limited trials indicate that students' historical awareness is good. Extensive trials in the exposure session showed that the students' historical awareness had reached the excellent category. This can be seen from the score indicators that approach 80 , that is, 79.4 .

\section{CONCLUSIONS}

Environment in which tertiary education develops has different characteristics from tertiary institutions in other regions. The historical aspect is the result of the adaptation of a long struggle to cultivate and maintain the environment. Banjarmasin City is an old city surrounded by wetlands; this area continues to grow based on historical evidence. Various activities such as the development of religion and culture can be seen from the physical, social and cultural heritage. Population development can be an indication of the development of various aspects and activities of Banjarmasin City, as well as the development of forms of government, namely the Sultanate to modern government. Continuity and change in Banjarmasin City in the form of various life activities is a source of historical learning. Learning history can be easier by looking at the evidence of events, to foster understanding, appreciation, awareness and historical skills.

Wetland environment where community life activities take place for centuries. This is evidenced by the existence of historical heritage objects. Historical learning models rarely use the environment as a source of history, learning always uses textbooks and student activity sheets. Learning material rarely relates to the student environment.

This model has transformed history learning into interesting and fun learning. Students wake up to get to know more about historical events. Historical awareness of students can be developed with scientific learning activities. Students can get to know historical sources firsthand, and have historical skills in the form of scientific reports and are responsible for presentations. The scientific learning model in the form of inquiry can foster student competence based on environmental characteristics, namely a combination of student centered learning in the form of contextual teaching learning and cooperative learning.

This combination of learning models shows that learning becomes fun and students can empathize with historical events and be able to imagine. Students have learning experiences according to curriculum demands and historical learning goals.

\section{ACKNOWLEDGMENTS}

We want to express special gratitude to all informants and anyone who has helped during the research. Especially the Faculty of Teacher Training and Education has provided research funding assistance and Department of History Education Study Program, Lambung Mangkurat University.

\section{REFERENCES}

[1] Shahroom, A., \& Hussin, N. (2018). Industrial revolution 4.0 and education. International Journal of Academic Research in Business and Social Sciences, 8(9), pp. 314-319. 
[2] Malmia, W., Makatita, S. H., Lisaholit, S., Azwan, A., Magfirah, I., Tinggapi, H., \& Umanailo, B. (2019). Problem-Based Learning as an Effort to Improve Student Learning Outcomes. Int. J. Sci. Technol. Res, 8(9), 1140114.

[3] Bihrer, A., Bruhn, S., \& Fritz, F. (2019). InquiryBased Learning in History in Inquiry Based Learning-Undergraduate Research, pp. 291299.

[4] Mestika Zed. (2010). Pengantar Filsafat Sejarah. Padang: UNP Press.

[5] Deans, J., \& Deans, H. (2018). A 21st Century Pedagogy Approach to environmental education in the early years.

[6] Soendjoto, M. A. (2016). Sekilas tentang LahanBasah dan Lingkungannya. Prosiding Seminar. Banjarmasin: Universitas Lambung Mangkurat.

[7] Porda, N.P.H. (2010). Gagasan Pendidikan Karakter melalui Revitalisasi dan Reaktualisasi
Budaya Lokal. Proceeding. Membangun Pendidikan Karakter dalam Perspektif Karakter dan Kebangsaan. Yogyakarta: Universitas Negeri Yogyakarta.

[8] Porda, N. P. H. (2015). Revitalisasi Nilai-Nilai Transportasi Tradisional dalam Pembelajaran IPS di Kalimantan Selatan. Prosiding. Tantangan IPS/IIS Dalam Dinamika Sosial Budaya. Bandung: UPI.

[9] Porda, N. P. H. (2019). Pengembangan Model Pembelajaran Sejarah Berbasis Lingkungan Lahan Basah untuk Meningkatkan Kesadaran Sejarah. Laporan Penelitian. Banjarmasin: FKIP ULM

[10] Sugiyono. (2015). Metode Penelitian dan Pengembangan (Research and Development). Bandung: Alfabeta. 